\title{
When Post-Realism (and the 1960s) Came to Iowa City: An Afterword - Robert F. Sayre
}

YOU MIGHT SAY that "Trouble-Making Fiction," or what we then called post-realism, and what the nation later called "the 1960s," all arrived in Iowa City on the same date, Friday afternoon, October 20, 1967. The occasion was a conference called "The New Grotesque, Or, Is There a Post-Realistic Fiction?" and the scene was the antiseptic ballroom of the Student Union, where Richard Poirier, author of $A$ World Elsewhere, a study of style in American Literature, was lecturing on "The Literature of Self-Parody."

With a polished combination of learning and humor (befitting the editor of the latter-day Partisan Review), Poirier had quoted examples of the intentional stylistic excesses of Henry James, James Joyce, and Norman Mailer, attacked modern writers who made the formal issues of fiction into the subjects of fiction, and then started a long aside on Jorge Luis Borges, describing him as the pre-eminent post-realistic author: a philosopher and novelist and jokester whose entire work was an examination of the world as fiction and the reality in fiction.

But Poirier was over his allotted time, and expressions on many faces said, as they do in Iowa City when professors from the East or West tell them what they already know, "Does this guy think we've never heard of Borges?" Everyone was also waiting for the next event, a "Eulogy to Lenny Bruce," by the man who was in a way the martyred sick comic's heir, Paul Krassner, editor of the underground satirical magazine - the dirty, deadly opposite of The Partisan Review - The Realist.

Then the doors at the back and sides of the ballroom opened quietly, and in came members of the San Francisco Mime Troupe, dressed in white sheets and holding candles. Chanting and moaning like monks, they came forward and formed a line across the front of the room. There, solemn and defiant, they blocked off the stage and barred anyone from going up to stop or rescue the suddenly distressed but still lecturing lecturer.

Who did quickly slip on stage were Ronnie Davis, the Mime Troupe's director, dressed in blue jeans and denim shirt, and Paul Krassner, also in jeans and jean jacket. There were a few brief words, no scuffle, and off went 
Davis with Poirier, still very tall and distinguished, but now being led away like an arrested embezzler. Krassner, seeming a foot shorter than Poirier, danced like a little boxer who had just won the fight and cockily headed for the lectern.

The audience could not seem to decide whether to cheer or hiss, until someone yelled, "What are you doing, Paul?"

"I'm taking a piss!"

And while everyone laughed (or nearly everyone), he pointed with one hand into the lectern, holding the other hand on his fly. "That guy went on so long, I have to. You probably do too. But I'm o.k. There's a urinal in here. That's how some guys can talk so long." He moved up close to the lectern and mimicked Poirier's stance.

The audience laughed and cheered louder, and Krassner went into his "eulogy." Bruce, he said, was really the first YIPPY, for Youth International Party, a political hippie, who had tried to reform America with laughter and ridicule. Bruce realized that the way to overcome an evil power was to grotesquely exaggerate it. This exposed the deformity already in it. That was what was so ironic about Bruce being arrested on obscenity charges: it was American sexual hang-ups that were obscene; Bruce had merely exposed them. So tomorrow, Krassner went on, the new yippies, in Bruce's spirit, were going to gather around the Pentagon and exorcise it. They were going to expose and release its grotesque and inhuman evil, not by tearing it down (like a Bastille) but with love. They would form a gigantic circle around it and pray and laugh and practice transcendental meditation until it rose, some gurus predicted, two feet off the ground.

"The New Grotesque" had started out to be a conference just on fiction, the "Second Biennial Conference for Modern Letters." The previous conference had been held in the fall of 1965 on "The Poet As Critic" and drawn a distinguished list of speakers and guests. The sponsors were the English Department and the Center for Modern Letters, which had been started in the spring of 1965 to take advantage of Iowa's leadership in the writing and study of modern literature. By 1967, however, the mood at The University of Iowa, as on other American campuses, was radically different. In 1965 the Vietnam War "escalation" had just begun and most professors and students were still ignoring it. You could still have a lecture on literary criticism by René Wellek or Richard Ellmann that would draw 500 to 700 
people. By 1967 the war was a horror to nearly everyone, and urban riots had engulfed dozens of American cities in fire and destruction. At the same time, the cool lingo of druggies, hippies, and dropouts was reaching from Berkeley and the Haight-Ashbury to Iowa City, Madison, and Ann Arbor. Thus, as we planned the 1967 conference we wondered about the relationships between modern fiction and this tense, brutal, and apocalyptic time. We wanted, or at least some of us wanted, a conference which would not ignore this and which would also confront the policies of the U.S. government and emphasize the relevance of anti-war satires and fantasies like Catch-22, Dr. Strangelove, and Cat's Cradle.

Beyond that, planning for the conference reflected the diverse interests of the people who were involved: Fred McDowell, as the director of the Center for Modern Letters; Vance Bourjaily, the Writers' Workshop's professor of fiction; David Hayman, who was then very interested in farce; Bob Scholes, who with Robert Kellogg had just published The Nature of Narrative; Kurt Vonnegut, who suggested having Krassner do the eulogy for Bruce; and a variable number of other English and Workshop peopleTom Whitaker, Fred Will, Bill Fox, George Starbuck, Gayatri Spivak, Bill Murray, Sherman Paul. In fact, the interests were so diverse and the senior faculty's explanations of them so intimidatingly complex that $I$, as a just-tenured associate professor, had little idea what the topic really was. We could never even agree on a conference title. "Black Humor" was the widely used term, but it seemed inappropriate because none of the authors mentioned was Black. "Bitter Humor" was too meek. "Novels of the Absurd"? Too close to Martin Esslin's Theatre of the Absurd. Other titles recognized still further aspects of the writing of the late '50s and early '60s: for example, "A Territory to Defend" and "The Novelist as Person." Then someone suggested calling it "Grotesques and Arabesques: The New Fiction," and through the summer of 1967 we used that title, though it seems awful, too. Too Poesque.

Looking further into old files, I also find a variety to the people we invited or talked about inviting that is staggering: Joseph Heller, Richard Kostelanetz, Robert Brustein, Irving Howe, J.P. Donleavy, John Hawkes, John Barth, James Purdy, John Updike, Bernard Malamud, Bruce Jay Friedman, R.W.B. Lewis, Warner Berthoff, Nathalie Sarraute, Alain Robbe-Grillet, Marcel Butor, Susan Sontag. Yet this babel of different voices suggests the difficulty of defining any new movement while standing 
in the middle of it. Twenty-five years from now, the list of participants considered for a conference in 1994 on, say, Post Modernism will surely look equally strange to the by-then wiser judges.

The person who had the most effect on the final list of speakers and guests was Bob Coover. He arrived in Iowa City in September of 1967 to start teaching at the Workshop and quickly began advising me and Bob Scholes, who either had just published or was about to publish The Fabulators. We shaped up the title ("The Old Grotesque," Coover now calls it), ${ }^{1}$ and when he found we still had money in the budget, he began suggesting more writers. Stanley Elkin, author of $A$ Bad Man. Robert Kelley, poet, novelist, and teacher. Roslyn Drexler, playwright, novelist, and former wrestler. Robert Stone, author of $A$ Hall of Mirrors. Sol Yurick, former Brooklyn welfare worker and author of a stunning novel about teenage gangs, The Warriors. And they all accepted, like a posse picked by a new sheriff. They made the conference into a gathering of a new generation of writers. William Gass, who later came entirely on his own, when he found out about the conference from John Barth, said recently that it was here that he first saw that he was not alone in his writing but was a part of a new generation. ${ }^{2}$

The trouble-making really began, however, with the arrival on Thursday, October 19, of the San Francisco Mime Troupe. Inviting them had been Scholes and Hayman's idea, for both had seen them perform in the parks of San Francisco and the Bay Area and recognized their adaptations of Commedia dell Arte as post-realistic theater that was also pre-realistic and a possible analog to what Scholes called "fabulism." But I had seen them in the summer of 1967 and realized that the most immediate fact about them was their political message. Their version of Goldoni's "L'Amant Militaire," a satire about the Spanish army in Italy, was a very funny, very angry attack on the American army in Vietnam. And when Peter Cohon, Sandy Archer, and a few other Mime Troupers found out that U.S. Marine Corps recruiters would be coming to The University of Iowa less than two weeks later, they incorporated that information into the Thursday night performance. At the end of the play, they took off their Commedia dell Arte masks and asked for commitment, not just laughter. "Take your opposition to this war and do something about it November 1. "Go tell it to the Marines.'" 
That night, at a party for the Mime Troupe given by graduate students Everett Frost, Faith Baron, and Harry and Linda MacCormack, a debate went on for hours about relations between art and politics. One side liked and admired the Mime Troupe actors for their political messages, which were clear not only in their words but also in their lifestyles. Another acknowledged the message but said their art and discipline were what put it across. They were actors first and last, for even when actors remove their masks, they still are actors. They would not "Go tell it to the Marines." They would have left town.

Such arguments engaged everyone, even those students who at normal parties chased girls or got drunk or smoked grass (or all three). This time, perhaps, it was the guests who made pests of themselves. "Who is that one-eyed ankle-grabber?" Chris Scholes asked her father during a party at Bob's house. "He's sitting at the top of the stairs grabbing the ankles of every girl going to the john." That, he told her, must be Robert Creeley.

Friday morning, however, Creeley added to the intensity of the arts/ politics debate by arguing that this moment of protest and revolution was not one at which to abandon language and the imagination. Seize them and be more persuasive, more powerful than the enemy. At one point, as dramatic a moment as when the actors had removed their masks the night before, Creeley stood up tall and thin, with his patch over one eye, pointed to some empty chairs on stage behind him, and said he could put people in them. "There, I see people in those chairs." And no one disputed him. Some people even assured me later that just then they saw people in the chairs, too.

At the same meeting Ronnie Davis made "realism" itself the enemy, the bulwark of status quo and the state, calling it "SatEvePost-Realism." A concept of reality existed only within a given frame. The Mime Troupe's method was to entice audiences into different frames of meaning and reference and then break them. Flip the frame and change the game. Audiences then saw connections they had not seen before. When someone accused Davis and his fellow actors of just being clowns, hired jesters, Jakov Lind spoke of his experience in World War II. Humor and ridicule were so offensive to the Nazis that they could land people in concentration camps.

The strongest defense of realism did not come until Saturday, the last day of the conference, from Carl Oglesby, a founder of the Students for a Democratic Society and the author, with Richard Shaull, of Containment and 
Change, the book on American foreign policy which was assigned reading for all members of the New Left. Acknowledging that reality was a fiction, Oglesby still insisted on the responsibility of the writer to confront hard facts, and this responsibility, he said, was shirked in most American fiction. His immediate example was Catch-22, which he painstakingly analyzed to prove that Yossarian's failure to kill Col. Cathcart was a cop-out and his impossible escape to Sweden a desertion from more than just the army. Oglesby compared Heller and Yossarian to Camus, saying that their "redefining of rebellion" gave it a "radically metaphysical and antipolitical meaning" which amounted to a "choice of political silence" and "a vote for oppression." 3 Metaphysical rebellions, like cries of despair and confrontations with the absurd, appealed to the upperclass and conservative.

The serious radicals listened to Oglesby attentively, even though some looked disappointed that he was being so literary. They wanted a Thomas Paine, and what they were hearing might as well have been just a left-wing English professor. Or they wanted to hear Paul Krassner again, someone who would be rowdy and funny, inspiring and optimistic. But Krassner had already left for Washington to help "levitate the Pentagon." Oglesby's message was the unpopular one that the revolution was not "all in our heads," as hippies said, but was going to take work, study, and commitment. But even Krassner had said to some of his admirers before he left that they ought to remember this moment, because it wasn't going to last. "It's going to turn ugly." 4

And he was right. On November 1, when the Marine Corps recruiters arrived, between 80 and 100 faculty and students blockaded the east entrance to the Student Union, trying to dissuade or prevent prospective recruits from going in for interviews. On the street in front, pro-war students gathered to heckle them and drag them from the steps. Hours passed, and eventually over 500 counter-demonstrators were yelling from the street and the parking ramp above. A riot pending, the police arrested the anti-war demonstrators. The story was on the evening news and front pages around the country, and arguments started all over the state about what the University should do. Was the University complicitous with the war? Should it protect the protestors' right to dissent or other students' rights to get jobs?

Even more trouble occurred on December 5, when Dow Chemical Corporation, makers of Napalm, came to interview. Students were beaten 
and maced by the police, and several were accused of a conspiracy to disrupt events all over the campus. Shortly afterward, the C.I.A. announced that it would not interview at The University of Iowa.

The trouble-making went on. And there was never another "Conference for Modern Letters."

\section{Notes}

1. Robert Coover, e-mail message to RFS, May 18, 1994.

2. William Gass, phone conversation with RFS, February, 1994.

3. Carl Oglesby, "The Deserter: The Contemporary Defeat of Fiction," Middle Earth, vol. 1, no. 4 (no date), p. 5. Middle Earth was the Iowa City underground newspaper founded in the fall of 1967. This issue reprinted Oglesby's talk. This and other issues of Middle Earth, as well as The Iowa Defender, the less flamboyant Iowa City "alternative paper," have been very useful to me in reconstructing the conference and its consequences. 4. Letter from Jim Ballowe to RFS, April 15, 1994.

In addition, I would like to thank Everett Frost, David Marr, Bob Scholes, and Fred Will, who also shared their memories of the conference, memories which were very sharp considering it all happened twenty-seven years ago. I wish I had had time to talk to more of us "Grotesque Alumni" and would welcome both corrections and further recollections. 